\title{
Land Rights and Nomadic Populations: Indigenous Perspectives
}

\author{
Karen Braun ${ }^{1 *}$ and S Jocelyn Davie ${ }^{2}$ \\ ${ }^{1}$ Ecología de Pastizales, Museo Argentino de Ciencias Naturales "Bernardino Rivadavia", Australia \\ ${ }^{2}$ CSIRO Ecosystem Sciences, Australia
}

Submission: March 20, 2019; Published: April 29, 2019

*Corresponding author: Karen Braun, Ecología de Pastizales, Museo Argentino de Ciencias Naturales "Bernardino Rivadavia", Australia

Keywords: Land rights; Herders; Indigenous peoples, Nomadism, Pastoral

\section{Spatial Mobility}

Spatial mobility implies a human movement towards resources, by contrast to the occidental-capitalist way of life in which resources are moved to and concentrated in the places where people are located. It is one of the ways that people respond to uncertain and changing environmental conditions. In some arid and highly variable environments there may be no fixed pattern to people's movements, also known as nomadism. However, mobility takes many other forms, including regular seasonal movements or transhumance, and permanent or semipermanent movements ('migration') [1]. Spatial mobility has long been a livelihood strategy for rangeland peoples, as it was for all the people in the world before agriculture was developed about 10,000 years ago. Although traditional nomadic ways of life are still strong in some areas, they tend to be in decline worldwide due to modernization, intensification of land use, and conflicts about land ownership and with wildlife conservation goals. However, in some cases, new transformed forms of mobility are on the rise.

Mobility is at the heart of the distinctive cultures of peoples whose ancestry and heritage is in arid, semi-arid and mountainous areas. It is an indivisible component of indigenous people's identity and spirituality, as well as their nature and territories. Mobility is a rational strategy for getting access to water, food, forage or other needs that are not always available in the same place or time due to landscape, climatic or seasonal variability. This strategy helps rangelands people to manage the risk that biophysical variability imposes on their livelihoods. It can promote recovery of plants (including pastures and timber), soil, fauna, and water after human use, preventing these resources from being permanently degraded. Thus, human mobility can contribute to sustainable use of natural resources.
Biodiversity and the ecosystem services of rangelands have often co-evolved with human mobility.

For some peoples, spatial mobility is related to hunting, fishing and gathering activities of family groups in which people move among favored camping and living areas. This may be combined with growing crops in small areas (for example corn, beans, Manihot, quinoa in parts of South America). For other peoples, spatial mobility is related to pastoral nomadism, in which people move around with domesticated livestock. or following wild herbivores migration or movements. Some pastoralists practice transhumance - regular seasonal movements between pasture areas that they have used for many centuries with long periods each year spent living at focal sites. Others move more opportunistically, following the pattern of rainfall. Strategies are influenced by the type of livestock, topography, climate and availability of water and forage. Some pastoral nomads are also hunters and gatherers. In all cases, mobile peoples' livelihoods rely on their intimate knowledge of water sources and the ecological dynamics of food resources and pastures. Their harvesting, pastoralist practices and ceremonial practices are directed at sustaining these resources. Indigenous people do not separate nature and people, unlike western cultures: taking care of nature and the environment is also taking care of themselves.

\section{Spatial Mobility and Dominant Cultures}

Customary forms of mobility have often been portrayed by people from the settled cultures that dominate most of the world as irrational, primitive and incompatible with modernization and private property. Also, government goals are often underpinned by neo-liberal philosophies that present discrete individual, family or corporate-owned parcels of private property as the optimal institution for economic development and 'progress'. 


\section{Ecology \& Conservation Science: Open Access}

Many governments have encouraged, or forced, mobile peoples to take up a settled way of life generally because governments want the indigenous lands to be privatized and owned by the dominant culture. Despite these attitudes, elements of nomadism have been adopted, thousands of years later, in 'modern' forms of pastoralism such as are practiced by ranchers or livestockstation owners in the rangelands of colonized countries. For example, in Australia, 'travelling stock routes' were established in the early days of European colonization as easements to enable livestock to be legally moved on foot between grazing areas across privately-owned or leased rangelands [2]. Now, most livestock are transported in trucks. Companies may own several rangeland grazing properties and move livestock between them, depending on where forage is available. Contemporary livestock owners also now ageist their cattle on properties owned by other people when seasonal conditions on their own properties are poor. These kinds of 'modern' practices show the enduring importance of mobility as part of a portfolio of strategies to manage resource variability in rangelands $[3,4]$.

In nations such as Australia, Argentina and Tanzania, nomadic indigenous peoples' way of life has been very greatly disrupted by colonization. Indigenous peoples were not recognized by colonizers as owners of their traditional territories and their land was taken over by agriculturalists and colonial ranchers with introduced livestock species. Land rights and indigenous' nations way of life continue to be disrupted in many countries by the development of agriculture, competition for water resources, oil and minerals extractions, tourism, or real estate business, all of them arguing for 'economic development'. In South America, the introduction of the climatically-versatile transgenic soybean and of plantations of exotic pine trees for the paper industry have led to a dramatic transformation of rangelands into privatelyowned agricultural or forestry lands, a process that has increased land social conflicts and environmental problems. There are also conflicts between indigenous peoples and 'modern' forms of pastoralism, which can be easier to resolve than conflicts with agriculture or mining. For example, in Australia, livestock station owners and indigenous people have negotiated for recognition of co-existing rights in some areas [5].

The establishment of conservation areas has brought conflicts with indigenous people that traditionally lived and owned those territories, especially when conservation areas are managed under a paradigm that does not consider people and their culture as compatible with goals for wildlife conservation. For example, in Tanzania, Masai people's lands were transformed into large 'wildlife conservation' areas that have not allowed Masai pastoralism. These kinds of conflicts continue even though a paradigm change is well underway in conservation philosophies [6]. The paradigm change considers nature and people in an integrated way: that is, cultures, languages and traditional life styles should be rescued and protected together with nature. Though sometimes criticized by indigenous people because it can be used to deny their right to develop a 'modern' way of life, this change in conservation practice has helped some groups to achieve their aspirations for the future of their communities and traditional lands. Under this new paradigm, different kinds of co-management strategies can take place, with different levels of participation of local indigenous people, including in decisions about resource management. Some examples are the co-managed National Parks in Argentina, in which Mapuce people co-manage protected areas with the National Parks Administration, and Indigenous Protected Areas in Australia [5], in which indigenous people own their land, managing it under IUCN protected area guidelines with economic and logistical support from the government.

Communally-owned property is an alternative to private property that is now being fostered by some governments and NGOs in rangelands and elsewhere for ownership, or access and use rights, and management responsibility of indigenous territories. This form of land-holding may provide for mobility of traditional pastoralists and hunter-gatherers but restrict that mobility to a defined area. In some legal systems, communallyowned property cannot be sold, transferred or inherited. This can reduce the pressure exerted by corporations or governments for economic exploitation of indigenous peoples' lands provided that other people respect these laws.

\section{New Forms of Mobility}

Access to new technologies has affected traditional forms of mobility of some indigenous nations. For example, Aboriginal people of central Australia move much greater distances now than they did traditionally, by travelling in cars along roads. One consequence is that important land management practices, such as burning to promote regeneration of plants and animal habitats, are now largely restricted to road corridors. Biodiversity is suffering as a result [7]. Aboriginal land-owners have started to use aircraft and aerial incendiaries to bring managed fire back to areas away from roads, with the support of regional organizations and funding from government and, in one case, through a greenhouse gas abatement contract funded by an energy company [8]. New communication technologies are also helping some pastoralists access information that aids their livelihoods. For example, in Mongolia, herders can use text messaging on mobile phones to get information about livestock prices at different markets, which helps them to decide where they should take their livestock for sale.

Loss of territory, together with loss of livelihoods and food security, forces many indigenous people to migrate to towns and cities looking for jobs to support their families. Alternatively, men might acquire temporary jobs in industrial agriculture at distant locations from their homes. Because culture and territory are indivisible components for indigenous people, these forms of mobility generally imply family dissolution and the loss of social bonds and traditions. Scientific research on the links between indigenous traditional ways of life and health is limited, but it tends to support the view that is common amongst indigenous 


\section{Ecology \& Conservation Science: Open Access}

people that their health is closely tied to their relationship to their land [9].

Internal migrations of indigenous people to urban centres are substantial in South America and Africa. This generally results in poverty of indigenous people and forced assimilation to the dominant culture together with discrimination and lack of access to education and health care. Similar strategies of 'periodic migration' in the very different context of the Ecuadorean Andes highlight that, inspite of the disruption to their traditional ways of life, some indigenous people are also taking advantage of markets, state programs and development interventions to build new hybrid livelihoods [10]. Urban migration is also a trend in Australia. The largest populations of Aboriginal people now live in big cities, in some cases because of dispossession from their land. For others, it is a strategy for easier access to schools, jobs, health care and other services that are not available on their traditional territories; or town-living itself is the attraction due to the loss of their own cultural traditions. A small proportion of Aboriginal people are successful in getting jobs in towns, generating income that maintains families and the social and cultural values of their home region. Australian governments have increased their expenditure on indigenous issues since 2007 aiming to 'close the gap' between Aboriginal and nonAboriginal people in health and other indicators of social disadvantage. However, this expenditure has to date had little impact on high levels of alcoholism and violence and low levels of literacy and employment amongst Aboriginal people [11].

In the Republic of Mongolia, pastoral nomads ('herders') and city populations come from the same cultural traditions. In past centuries almost all Mongolians were herders, however, this declined with development of work in government, service industries, mining and growth of towns and the capital city. In the early 1990s when many Mongolians returned to a herding way of life after private ownership of livestock was instituted by governments following forty years of collectivized grazing. This renewed involvement in herding has not been sustained. The number of people employed in herding declined by nearly $10 \%$ between 2003 and 2009 even though the total population of Mongolia grew by over $9 \%$ during this period. In 2009, only $35 \%$ of the Mongolian workforce remained as herders $[12,13]$. Herding is a more difficult way of life now than it was during the collectivized period because there is now less government investment in infrastructure and services to help herders access services and markets or to manage risk, such as from very severe winter conditions ('dzud'). Herders tend to be much less mobile as a result [14]. For example, state support for education of herder's children in boarding schools has been reduced, resulting in more herders grazing their herds close to towns so that their children can go to school [15].

\section{Conclusion}

In summary, nomadism has long been culturally important to rangeland peoples and critical to sustainability of their livelihoods and identity. The spatial mobility involved in nomadism and transhumance is a strong adaptation to the variability of rangeland ecosystems in space and time and it promotes sustainable use of resources. However, it often conflicts with capitalist/neo-liberal concepts of private property and economic development and with non-cultural conservation paradigms. Indigenous people have their own unique experiences and perspectives of land rights and mobility. Communally-owned property and indigenous co-management or management of conservation or rural areas with government support are alternatives to re-think and create new cultural and environmentally sustainable paradigms of development and resource use.

\section{Acknowledgement}

Thanks to Margaret Friedel and Jane Addison for review comments that have improved a draft of this article. We also thank the indigenous people who we work with for insights to issues that impact on their lives.

\section{References}

1. Fernandez-Gimenez ME, Le Febre S (2006) Mobility in pastoral systems: Dynamic flux or downward trend? International Journal of Sustainable Development and World Ecology 13(5): 341-362.

2. Cameron JMR, Spooner PG (2010) Origins of Travelling Stock Routes. 2. Early development, management, and the growing embrace of the law (1830-70s). The Rangeland Journal 32(3): 341-351.

3. Hobbs NT, Galvin KA, Stokes CJ, Lackett JM, Ash AJ, et al. (2008) Fragmentation of rangelands: Implications for humans, animals, and landscapes. Global Environmental Change-Human and Policy Dimensions 18(4): 776-785.

4. McAllister RJ, Gordon IJ, Janssen MA, Abel N (2006) Pastoralists responses to variation of rangeland resources in time and space. Ecological Applications 16(2): 572-583.

5. Davies J (2011) Relationships have been important for Aboriginal influence on Australian policy. In Proceedings IX International Rangelands Congress, Rosario, Argentina.

6. Phillips A (2003) Turning ideas on their head: The new paradigm for protected areas. George Wright Forum 20(2): 8-32.

7. Edwards GP, Allan GE, Brock C, Duguid A, Gabrys K, et al. (2008) Fire and its management in central Australia. The Rangeland Journal 30(1): 109-121.

8. Russell-Smith J, Murphy BP, Meyer CP, Cook GD, Maier S (2009) Improving estimates of savanna burning emissions for greenhouse accounting in northern Australia: limitations, challenges, applications. International Journal of Wildland Fire 18(1): 1-18.

9. Davies J, Campbell D, Campbell M, Douglas J, Hueneke H, et al. (2010) Livelihoods in Land: Promoting health and wellbeing outcomes from desert Aboriginal land management. Research Report 78. Desert Knowledge CRC. Alice Springs.

10. Bebbington A (2000) Reencountering development: Livelihood transitions and place transformations in the Andes. Annals of the Association of American Geographers 90(3): 495-520.

11. SCRGSP [Steering Committee for the Review of Government Service Provision] (2009) Overcoming Indigenous Disadvantage: Key Indicators 2009. Productivity Commission, Canberra. Productivity Commission, Canberra. 
12. Medsaikhan S, Gerelt-Od G, Ersenesuren B, Ganbat B, Bajikhuu Kh (2010) Mongolian Statistical yearbook 2009. Ulan Bataar, National Statistical Office of Mongolia.

13. NSOM (National Statistical Office of Mongolia) (2007) Mongolian Statistical yearbook 2006. Ulan Bataar, National Statistical Office of Mongolia.
14. Fernandez Gimenez ME (2006) Land use and land tenure in Mongolia: a brief history and current issues. USDA Forest Service Proceedings RMRS-P 39: 30-36

15. McAllister (2012) Livestock mobility in arid and semi-arid Australia escaping variability in space and time. R J in press Pastoralism 34(2): 139-147.

\section{Your next submission with Juniper Publishers} will reach you the below assets

- Quality Editorial service

- Swift Peer Review

- Reprints availability

- E-prints Service

- Manuscript Podcast for convenient understanding

- Global attainment for your research

- Manuscript accessibility in different formats ( Pdf, E-pub, Full Text, Audio)

- Unceasing customer service

Track the below URL for one-step submission https://juniperpublishers.com/online-submission.php 